\title{
The Relationship Between the Use of School Learning Facility and A Job Training Experience Toward Vocational School Student Readiness Level
}

\author{
$1^{\text {st }}$ Fatkhur Rochman \\ Vocational Education (PKJ) \\ State University of Malang \\ Malang, Jawa Timur Indonesia \\ rochman.fatkhur107@gmail.com
}

\author{
$2^{\text {nd }}$ Waras Kamdi \\ Vocational Education (PKJ) \\ State University of Malang \\ Malang, Jawa Timur Indonesia \\ waraskamdi@gmail.com
}

\author{
$3^{\text {rd }}$ Amat Mukhadis \\ Vocational Education (PKJ) \\ State University of Malang \\ Malang, Jawa Timur Indonesia \\ Mukhadis_s@yahoo.com
}

\begin{abstract}
The main mission of Vocational High School (SMK) is to prepare learners as prospective workers who have readiness in entering the world of work. One indicator of the level of readiness of work can be obtained bv the students in the form of the use of optimal learning tools in schools and industrial job training experience. This study aims to determine the relationship between the use of learning facilities in schools and the experience of industrial iob training on the level of readiness of vocational students. This research is included in the type of quantitative research. The population in this study were all students of SMK in Lamongan Regency with the sample used as many as 170 students. Data collection was done by questionnaire. The analvsis technioue usedin this research is a correlation with product moment correlation and multiple regression techniques. The result of the research shows: (1) there is a significant correlation between the use of learning facilities in school to the level of readiness of vocational students, (2) there is significant relation between industrial work training experience to the level of readiness of vocational students, and (3) the use of teaching and learning facilities in schools and the experience of industrial job training on the level of readiness of vocational students.
\end{abstract}

Keywords-Correlation; The Use of School Learning Facility; a Job Training Experience; Work Readiness Level

\section{INTRODUCTION}

The development of science and technology and the demands of globalization together have resulted in increasingly fierce competition in the provision of superior human resources. In order to continue to maintain its competitiveness, existing human resources are required to continuously improve their knowledge, skills, attitudes, and values or competencies, so that everyone should be able to become lifelong learners. However, based on the results of studies, observations, and research, the development effort faces many obstacles in the field, which needs to find an alternative solution. According to Fauzi [1] in the 2016 human development report, Indonesia's Human Development Index (HDI) in 2015 is ranked 113, down from the 110th position in 2014. This shows that the quality of
Indonesian human resources is still low and needs to be improved compared to other countries.

The low quality of Indonesian human resources, has an impact on the high unemployment rate in Indones ia. Based on data from the Central Bureau of Statistics (BPS) [2], the number of unemployed people increased by 300,000 to 7.45 million people per February 2015. The highest unemployment rate (TPT) occurred in educated societies with $9.05 \%$ of vocational school graduates (SMK). Compared to February 2014, an increase of 1.84 points. Furthermore, the second largest TPT is high school graduates (SMA) with a portion of $8.17 \%$. For Diploma I/I/III TPT of $7.49 \%$. TPT diploma graduates increased by 1.62 points from February 2014. Meanwhile, junior high school graduates were unemployed $7.14 \%$, university $5.34 \%$ and elementary school (SD) down 3.61\%. (http:/www.bps.go.id). From the data above shows that Vocational School (SMK) the largest contributor to unemployment in Indonesia.

Vocational High School (SMK) is an educational institution that provides education at the middle level that emphasizes more equip students with skills, in accordance with the field chosen. SMK prepares students to be a tenacious, persistent person, and produces graduates who have the skills, discipline and attitude as an effort to prepare students to enter the workforce. Vocational education has a special characteristic that distinguishes it from other types of education. In the Law of the Republic of Indonesia Number 20 The year 2003 on National Education System (Sisdiknas), the explanation of Article 15 states that vocational education is a secondary education that prepares students primarily to work in a particular field.

SMK has a very important role to prepare students to be ready to work, either work independently (entrepreneur) or fills vacancies. Therefore, the direction of the development of vocational secondary education is oriented towards the fulfillment of labor market demand. SMK as one of the institutions that prepare the workforce, is required to produce graduates as expected by the world of work. Manpower needed is human resources which have competence in 
accordance with the field of work, has a high adaptability and competitiveness [3].

The existence of SMK to prepare its graduates to become skilled and professional workforce still needs to be improved because not all SMK graduates can fulfill job demands according to their competence or skill. In the study of Callan and Clarke [4] it is pointed out that there is still a gap between the world of education and the world of work where the world of education sees graduates who have high competence are those who graduate with high value in quick time, while the industry wants the high competence of graduates with technical skills and good attitude. Facts in this field indicate that the implementation of vocational education and training runs its own program, on the other hand the world of work/industry and professional associations often complain that the quality of graduates has not fulfilled the expected competence demands.

Symptoms of mismatch between educational institutions and vocational training with business/industry, ultimately gave birth to underqualified graduates. Such a situation has long been happening, even today. This is caused by various things, which is fully organized by the school is less able to adjust to the changes and development of the world of work, so that the readiness of the students to be less.

The readiness for work is a condition of a person that shows the existence of harmony between skills, knowledge, attitude/mental, and individual experience to be able to work [5]. Furthermore, the readiness of this work becomes very important for students of SMK because the student is the hope of the community to become graduates who have the competence according to their field in order to generate new innovations to meet the needs of the community.

One of the important factors that determine whether or not the graduates of SMK ready to work or enter the workforce is the use of learning facilities in schools. The use of learning facilities in schools is the utilization of all facilities and infrastructure facilities to support learning for the achievement of learning objectives and education optimal, effective and efficient. Learning facilities are able to clarify the needs of learners in achieving educational goals. This is in line with the opinion [6] where the means of learning is the most important element of the school where high quality of education can't be realized by means of simple learning. A student in doing learning activities require a certain encouragement so that learning activities can produce competence in accordance with the expected goals.

Learning facilities is a requirement that must be met in the vocational education system that aims to provide the provision of skills and knowledge for the graduates into the productive workforce. Skills and knowledge will be well acquired if the vocational school students learn by means of infrastructure and places that suit their field of work later. Learning facilities will give effect in the smoothness of teaching and learning process. According to [7] states that if complete learning tools that can be utilized and owned by students, then the impulse in students to learn will be greater, and students will be more eager in learning and efforts will be more optimal. The use of the optimal learning tools greatly affects the level of readiness of students in entering the workforce.

Students who are ready to work in addition to having extensive knowledge, use of optimal learning tools in schools, are also supported by the experience they have. Working experience in business/industry unit (DU/DI) is also needed by students to enter the work world with intense competition. Skills and experience will be well acquired if the vocational school students learn by means of infrastructure and place in accordance with the field of work later. Dalyono [8] suggests that experience can affect the physiology of individual development which is one of the principles of development of readiness of learners in preparing to enter the world of work. Student's experience is one of them with industrial job training program.

Industrial job training is a learning program that involves students directly working in DU/DI. The program is held as a concrete manifestation of the implementation of the education system in vocational education in the form of Dual System Education (PSG). Industrial job training programs are organized together between schools and the world of work in order to meet learners' needs for competence and real experience. The job training program in the industry aims to have students competence in accordance with the expectations and demands of DU/DI, as well as to obtain work experience as one of the things to improve professional skills. Through the job training program in this industry, students' experience and insights about the real world of work will increase so that students are expected to have a high level of job readiness.

Experience while conducting job training in the industry, directly related to the level of readiness of vocational students. This is because the job training experience in the industry is related to the skills and knowledge aspects as well as the mental aspects of the students. In this job training activity in the industry students learn to apply the knowledge or skills acquired in school directly as well as gain additional skills that are not obtained in school. In the industry students are required to learn to adjust to the work environment, work under pressure, work independently, responsibly, critically, creatively and innovatively.

Based on the above explanation, the most important thing to do to help provide one of the solutions for the purpose of vocational high school is to make the learning done in the schoolcan prepare learners who are ready to work according to the demands of the world of work. Therefore, the purpose of this research is to know the level of readiness of student work and its relation to the use of learning facilities in school and experience of job training in the industry. The results obtained are expected to be the basis of consideration in taking the policy to improve the quality of vocational school graduates.

\section{METHOD}

This research uses quantitative research approach with survey method. Research using survey method focuses on the disclosure of relationships between variables, namely a study directed to investigate the relationship of cause based on observations of the consequences that occur, with the aim of separating the relationship of a variable causal to the variable 
effect. The testing technique uses product moment correlation and multiple regression analysis.

The population of this study are public and private vocational students in the field of Computer and Network Engineering Expertise Study (TKJ) In Lamongan District, East Java, who have attended job training in Business World/Industrial World (DU/DI). The population of this study were students of SMK Negeri 1 Sambeng which amounted to 66 students, SMK Negeri 2 Lamongan 72 students, SMK Muhammadiyah 5 Babat amounted to 71, and SMK Sunan Drajat Lamongan amounted to 85. The total population of this research is 294 students. Sampling was done by using proportional random sampling technique. Determination of sample size to be used from the population is done by using random number table with the error rate $\alpha=5 \%$, then the sample used is 170 students.

The research instrument used to get data about 3 variables studied namely; (1) the use of learning tools in schools, (2) industrial job training experience, and (3) the level of work readiness. The data collection of the three variables is done by using a questionnaire with 4 Likert scales. Size is proportionately more than custom. These and other measures are deliberate by using a specification that anticipates your paper as part of a whole process, and not as an independent document. Please do not revise any of the current titles.

\section{RESULTS}

\section{A. Data Description}

Data descriptions for variables of use of learning facilities in schools, experience industrial job training and work readiness levels can be seen in Table 1 .

T ABLE 1. DAT A DESCRIPTION EACH VARIABLE

\begin{tabular}{|c|c|c|c|c|c|c|}
\hline Variable & Mean & Median & $\begin{array}{c}\text { St. } \\
\text { De viation }\end{array}$ & Range & Min & $\max$ \\
\hline $\begin{array}{l}\text { Use of } \\
\text { School } \\
\text { Learning } \\
\text { Facilities } \\
\text { (X1) }\end{array}$ & 78,46 & 78,00 & 7,69 & 42,00 & 52,00 & 94,00 \\
\hline $\begin{array}{l}\text { Industrial job } \\
\text { training } \\
\text { experience } \\
\text { (X2) }\end{array}$ & 89,72 & 90,00 & 8,76 & 46,00 & 67,00 & 113,00 \\
\hline $\begin{array}{l}\text { Work } \\
\text { readiness } \\
\text { level (Y) }\end{array}$ & 109,15 & 109,00 & 9,56 & 43,00 & 88,00 & 131,00 \\
\hline
\end{tabular}

Based on Table 1 on the variable Use of School Learning Facilities (X1) it is known that the average is 78.46 with the middle value of 78.00 standard deviations of 7.69 and the range of 42.00. The highest score was 94 and the lowest score was 52. In the industry work experience (X2), the average was 89.72 with the mean of 90.00 standard deviations of 8.76 and the range of 46.00. The highest score is 113 and the lowest score is 67. At the work readiness level (Y), the average is 109,15 with the mean value of 109,00 standard deviation 9,56 and the range is 43,00 . The highest score is 131 and the lowest is 88 .

\section{B. Test Result}

After the whole prerequisite test is done and obtained according to the criteria it will be tested the analysis to test the hypothesis that has been proposed. Hypothesis test analysis used is correlation analysis with Product Moment correlation technique and multiple linear regression with the help of SPSS 20 for Windows program. This analysis aims to find out the relationship between the variables of the use of learning facilities in school (X1) with the level of job readiness (Y), and the experience of industrial job training (X2) with the level of job readiness (Y). Significant decision-making is based on the $p$ value $<0.05$. The results obtained can be seen in the following table:

TABLE 2. SUMMARY OF CO RRELATION ANALYSIS RESULTS

\begin{tabular}{lccc}
\hline Variable & $\begin{array}{c}\text { Correlation } \\
\text { Coefficient }(\mathbf{r})\end{array}$ & Sig. & Description \\
\hline $\mathrm{X}_{1}-\mathrm{Y}$ & 0,480 & 0,000 & Significance \\
$\mathrm{X}_{2}-\mathrm{Y}$ & 0,449 & 0,000 & Significance \\
\hline
\end{tabular}

The first hypothesis testing was conducted to find out the relation of the use of learning means (X1) with the level of job readiness (Y). Based on table 2 got the result of the analysis of significance value of 0,000 and the correlation coefficient (r) of 0.480 . With significance level $<0.05$ then Ho is rejected. Decision-making can also be done by comparing tcount with ttable. If tcount $>$ ttable, then $\mathrm{Ho}$ is rejected, otherwise if $\mathrm{t}$ count <ttable, then Ho accepted. Obtained a tcount of 5.804 and seen ttable ( $\mathrm{df}=100-1$, two tail $/ 5 \%$ ) of 1.974 , it is known tcount> ttable which means the hypothesis is accepted. It can be concluded that there is a significant relationship between the use of learning facilities in schools on the level of readiness of vocational students.

The second hypothesis testing is done to know the relation of experience of job training industry (X2) to work preparedness level (Y). The analysis results obtained significance value 0.000 and correlation coefficient (r) of 0.449 . With significance level $<0.05$ then $\mathrm{Ho}$ is rejected. Decision-making can also be done by comparing tcount with ttable. If tcount $>$ ttable, then $\mathrm{Ho}$ is rejected, otherwise if $\mathrm{t}$ count <ttabel, then Ho accepted. Obtained a tcount of 5.150 and seen ttable ( $\mathrm{df}=100-1$, two tail $/ 5 \%$ ) of 1.974 , it is known tcount $>$ ttabel which means the hypothesis is accepted. It can be concluded that there is a significant relation between industrial work training experience to the level of readiness of vocational students.

The third hypothesis testing was conducted to examine the relation between the use of learning facilities at a school (X1) and the experience of industrial job training (X2) simultaneously on the level of readiness of work (Y). The result of the third hypothesis test using multiple linear regression analysis with criteria of significance value $<0,05$. Based on table 3 obtained significance value of 0.000 then Ho is rejected. Decision-making can also be done by comparing $\mathrm{F}$ count with Ftable. If the statistic F count is <Ftable, then $\mathrm{H} 0$ is 
accepted, otherwise if the statistic Fcount $>$ Ftable, then H0 is rejected. With the degree of freedom 95 and 5\% significance level, obtained Fcount of 42.23, so Fcount (42.23)> Ftable (3.05). It can be concluded that there is a significant relationship between the use of learning facilities in schools and the experience of industrial job training on the level of readiness of vocational students.

TABLE 3. MULTIPLE REGRESSION COEFFICIENT RESULTS

\begin{tabular}{lccccc}
\hline & \multicolumn{5}{c}{$\begin{array}{c}\text { Standardized } \\
\text { Coefficients }\end{array}$} \\
\cline { 2 - 5 } \multicolumn{1}{c}{ Model } & B & $\begin{array}{c}\text { Std. } \\
\text { Error }\end{array}$ & Beta & t & Sig. \\
\hline (Constant) & 38,656 & 7,703 & & 5,019 & 0,000 \\
$\begin{array}{l}\text { Use of School } \\
\text { Learning Facilities }\end{array}$ & 0,475 & 0,082 & 0,382 & 5,804 & 0,000 \\
$\begin{array}{l}\text { A Job Training } \\
\text { Experience }\end{array}$ & 0,370 & 0,072 & 0,339 & 5,150 & 0,000 \\
\hline
\end{tabular}

a. dependent variable: Work Readiness Level

From the results of multiple linear regression analysis can be known the amount of Effective Contribution (SE) predictors of the criteria. The amount of effective contribution of independent variables includes the use of learning facilities in schools and experience of industrial job training on the level of readiness of vocational school students obtained from Rsquare of 0.336 . This means that both independent variables give influence of $33,6 \%$ to the dependent variable.

\section{DISCUSSION}

\section{A. Relationship between Use of School Learning Means on Work Readiness Level}

The results showed that there was a significant correlation between the use of learning facilities in schools on the level of work readiness shown rxly of 0.480 and sig probability. 0,000 $(<0.05)$. With $\mathrm{t}$ test obtained $\mathrm{t}$ count $=5,804$ and $\mathrm{t}$ table equal to 1,974 where tcount is bigger than ttable or $5,804>1,974$. This indicates that the use of learning facilities in schools has a role in influencing the level of readiness of students work.

This is in accordance with research Taufik Nur [9] which shows the results of analysis using a simple regression obtained price coefficient of determination of 0.184 . This shows that the feasibility of the workshop has a positive effect on the readiness of students of class XI of mechanical engineering skills program SMK N 2 Yogyakarta. A decent workshop, of course, will facilitate students in the use of learning tools and practice the material gained. Students who are easy in practicing of course will be better prepared in facing the world of work.

According to Suswanto and Roniwijaya [10] the use when connected with learning facilities, especially the practice facility that is using or utilizing the means of learning available to achieve the desired learning objectives. Thus it can be said that the better the perception of students about the use of learning facilities in school, the better the level of readiness of students. Therefore, the use of learning facilities in schools is significantly related to the level of readiness of vocational students.

\section{B. Relationship The experience of industrialjob training on Work Readiness Levels}

The results showed that there was a significant relationship between the experience of industrial job training on the level of readiness of work shown $\mathrm{Rx} 2 \mathrm{y}$ of 0.449 and sig probability. $0,000(<0.05)$. With $t$ test obtained $t$ count $=5,150$ and ttabel equal to 1,974 where tcount is bigger than ttable or $5,150>$ 1,974. This indicates that the experience of industrial job training has an important role in influencing the level of readiness of students work.

In accordance with research [11] revealed that industry job training variables positively affect the readiness of work significantly. The magnitude of the effect of job training variables on work preparedness is $3.76 \%$. This means that the better the industry's job training program results in better job readiness for students. The results of research Putriatama [12] proved When viewed partially experience of industrial job training students have a positive and significant impact on students' work preparedness. The magnitude of the partial and direct influence of the industry's job training experience on students' readiness is 0.125 or rounded to $13 \%$. Thus, the high level of students' readiness is influenced by $13 \%$ industry job training experience. According to research Lestari and Siswanto [13] stated that Contributions provided by industry job training experience to job readiness of $24.9 \%$ if other variables are controlled with a coefficient of determination of $24 \%$.

The experience of industrial job training that is obtained by students in the industry is expected to implement the knowledge that students have acquired during the school, so that when the industrial work training activity has been completed, students have the level of mental and material readiness in entering the real world of work.

\section{Relationship Use of School Learning Facilities and Experience Industrial job training on Work Readiness Level}

The result of the research shows that there is a significant correlation between the use of learning facilities in schools and the experience of industrial job training on the level of readiness of vocational students. This is indicated by the sig probability value. $0,000(<0.05)$ and Fcount $(42.23)>$ Ftable (3.05).

The total effective contribution of the two variables obtained from Rsquare is 0.336 . This means that the optimal use of learning tools in schools and appropriate industry job training experience can influence jointly to the level of readiness of vocational students of $33.6 \%$.

The better the use of learning facilities in schools will have an impact on students in obtaining the desired knowledge and skills so that students have a degree of readiness in the face of the world of work. Similarly, the experience of industrial job training, According to [13]the implementation of industrial job training provides experience for students to work directly in 
the industrial environment. It provides additional knowledge about the world of work that students do not get in school.

In line with the opinion of Maryani [14] level of readiness of work can be formed, studied and developed through learning experience gained in school. One of the readiness that is established through the experience gained in school is the readiness to work in the industry, because in reality they gain experience to work in the industry based on the work experience of industry/internship that has been implemented. So the better the use of learning facilities in schools and the quality of industrial work training students undertaken in DU/DI then the level of readiness of students in the face of the world of work will be fulfilled [15].

\section{CONCLUSIONS AND SUGGESTION}

From the result of the test, it can be concluded that: (1) There is a significant correlation between the use of learning facilities at school with the level of readiness of vocational students with significance $(0.000)<0,05$, (rxly) of $7.84 \%$, and Tcount $(5,807)>$ Tables $(1,974)$; (2) There is a significant relation of experience of industrial job training with level of readiness of vocational students with significance $(0.000)$ $<(0,05)$, (rxly) equal to $7,84 \%$, and Tcount $(5,150)\rangle$ Ttable $(1,974)$; (3) There is a correlation between the use of learning facilities in schools and the experience of industrial job training significantly on the level of readiness of students of SMK with Fcount of 42.230 and significance $(0.000)>(0,05)$; (4) The Effective Contribution (SE) variable of the use of learning facilities in schools and the experience of industrial job training on the level of readiness of vocational students is $33.6 \%$, the remaining $66.4 \%$ influenced by other variables.

Based on the conclusions and limitations of the research contained in this study, suggestions that can be given by researchers are as follows. First, the industry party is also expected to allow the students to directly work in the workplace of the industrial workshop so that the learning outcomes and readiness to enter the workforce will grow with the activities, experience and knowledge they get in school can be in accordance with what they receive in the industry job training. Second, the School as the organizer of all school activities should pay more attention to facilities and infrastructure in the learning process that must be in accordance with the ratio of the number of students so that students can use the equipment in accordance with the world of work. Third, Students are expected to improve the competence of both cognitive, affective, and psychomotor skills that support the improvement of their competence. As well as maximizing the role at the time of industrial job training so that students have readiness in the face of the world of work.

\section{References}

[1] Fauzi, Yuliy anna, 2017. Rangking indeks Pembangunan Manusia Indonesia.

(https://www.cnnindonesia.com/ekonomi/20170322182446-78202081/ranking-indeks-pembangunan-manusia-indonesia-turunke-113/) Diakses 1 September 2017.

[2] Badan Pusat Statistik. 2014. Tingkat Pengangguran Terbuka Menurut Pendidikan Tertinggi yang Ditamatkan 2004 - 2014. (http://www.bps.go.id/tab_sub/view.php?kat=1\&tabel=1\&daftar= 1\&id_suby ek=06\&notab=4) diakses 10 September 2014

[3] Dikmenjur. 2004. Kurikulum SMK. Jakarta: Dikmenjur.

[4] Baiti, A. A. \& Munadi, S. 2014. Pengaruh Pengalaman Praktik, Prestasi Belajar Dasar Kejuruan dan Dukungan Orang Tua Terhadap Kesiap an Kerja Siswa SM K. Jurnal Pendidikan Vokasi, 4 (2): 164-180.

[5] Yanto, F. 2006. Ketidakpastian Memasuki Dunia Kerja karena Pendidikan. Jakarta: Dinamika Cipta.

[6] Muiaddi Choirul IJmam 2014 Intonsitas Pomhelaiaran Praktik di Innit Produksi/Iasa. Sarana dan Prasarana Innit Produksi/Iasa dan Motivasi Relaiar Siswa Huhunoannva dengan Kompetensi Kerja Siswa SMK Negeri di Kota Surabaya. Tesis tidak dipulikasikan. Malang PPS-UM.

[7] Nurdin. 2011. Pengaruh Minat Baca, Pemanfaatan Fasilitas dan Sumber Belajar Terhadap Prestasi Belajar IPS Terpadu SMP Negeri 13 Bandar Lampung. Jurnal Ekonomi \& Pendidikan, 8 (1): $88-101$.

[8] Dalyono. 2012. Psikologi Pendidikan. Jakarta: Rineka Cipta.

[9] Taufik Nur, A. 2016. Pengaruh Kelayakan Bengkel Pemesinan dan Prestasi Belajar Pemesinan Frais terhadap Kesiapan Kerja sebagai Juru Frais. Jurnal Pendidikan Vokasional Teknik Mesin, 4 (8):569-576.

[10] Suswanto, M. \& Roniwijaya, P. 2015. Korelasi antara Pemanfaatan Fasilitas Praktik dan Minat Siswa dengan Hasil Belajar Siswa SMK Muhammadiyah Suruh Kabupaten Semarang. Jurnal Taman Vokasi, 3 (2):730-736.

[11] Muktiani, Eka E. 2014. Pengaruh Praktik Kerja Industri dan Prestasi Akademik Mata Diklat Produktif Akuntansi terhadap Kesiapan Kerja Siswa Kelas XI Program Keahlian Akuntansi SMK Nasional Pati Tahun Pelajaran 2012/2013. Economic Education Analysis Journal (EEAJ), 3 (1): 166-172.

[12] Putriatama, E., Patmanthara, S., \& Sugandi, R.M. 2016. Kontribusi Pengalaman Prakerin, Wawasan Dunia Kerja dan Kompetensi Kejuruan melalui Employability Skill serta Dampaknya terhadap Kesiapan Kerja Lulusan SMK Kompetensi Keahlian Teknik Komputer dan Jaringan di Probolinggo. Jurnal Pendidikan, 1 (8): 1544-1554.

[13] Lestari, I. \& Siswanto, B. T. 2015. Pengaruh Pengalaman Prakerin, Hasil Belajar Produktif dan Dukungan Sosial Terhadap Kesiapan Kerja Siswa SMK. Jurnal Pendidikan Vokasi, 5 (2): 183-194

[14] Mary ani, P. 2012. Kontribusi Bakat Mekanik dan Proses Belajar Pada Mata Pelajaran Produktif Terhadap Kompetensi serta Kesiapan Kerja Siswa untuk bekerja di Industri. Jurnal INVOTEC, 8 (2): 167-178.

[15] A. B. N. R. Putra, W. Irdianto, A. Mukhadis, and S. Suhartadi, "Pocket Book Learning: Learning Methods to Train Students Productive and Creative Using 'BRANO' as an Effective Learning Recorder," in Proceedings of the International Mechanical Engineering and Engineering Education Conferences (IMEEEC-2016), 2016, vol. 30034, p. 30034 . 